\title{
Bioweapons - A Review
}

\author{
Karan Singh Negi, Shivani \\ Govt. Mohindra College, Patiala, Punjab, 147001, India
}

\begin{abstract}
Bioterrorism is the aforethought manoeuvring of bioweapons during wars. Many genetically engineered microbes, Bacillusanthracis, Clostridiumtetani, Yersiniapestis are being used in the terms of aerosol sprays, explosive materials and through contamination of natural resources of food, water and land to inflict bio war. Their implementations during war strengthen over the use of conventional weapons due to their ability of fabricating more diseases or to contaminate much of the population and causes adverse effect on their survival. Noble and accessible technologies make them to proliferate which have implications for regional and global security. To make them disinfected or to be protected from them, there is a need of leadership, and many preventive and protective strategies have been enacted through international consultation and cooperation. The exploitation of these genetically engineered microorganisms leads to the enhancement of pollutants in the environment and natural sources of land, air and water. Most of the pollutants among them are Bacteria, pollens, particulate matter, toxic gases, etc. So, some biosafety measures should be taken into consideration to safeguard the people from the harmful effects of these weapons.
\end{abstract}

Keywords: Bioterrorism, Bioweapons, Microorganisms, Pollution

\section{Introduction}

Humans have used all the technologies and methods known to them for destruction. Besides the conventional methods of destruction there is also the development of new weapons of mass destruction which are called as Bioweapons. If some terrorists can get the hold of these weapons then there will be a global devastation for sure. According to some historical evidences during 18 century (1754-1767) when Britishers distributed the blankets of smallpox patients to the Native Americans the mortality rate increased to about $50 \%$.So the increased use of these biological weapons contributes to the Bio-war._(Alok Kumar, 2011). Many countries started using these biological weapons instead of the conventional nuclear bombs as their impact is immediate whereas the bioweapons are slow in causing destruction and they cause mass destruction. The average mortality rate by bioweapons is 50 times more than the conventional nuclear weapons, a report says.

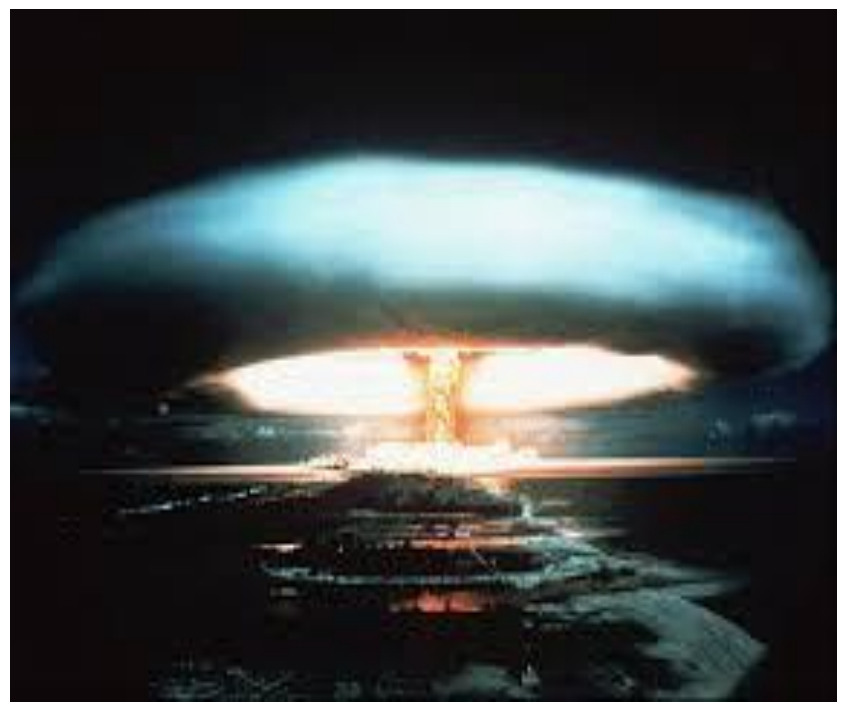

Dispute between two nations or between two conflicting parties with in a nation leads to war. These wars have much effects or consequences on public health environment and environmental sources.
Also the use of these bioweapons and other military and war activities lead to the contamination of the environmental sources like: water bodies, plants and trees, aquatic life and animals which leads to war pollution.

This pollution and wars are going with each other. This war pollution leads to mass destruction of environment. Usage of poisonous gases in WWI and chemicals in WWII effects the environment and population till today.

Pollution and serious diseases caused by the bioweapons such as anthrax, small pox etc. is serious topic of discussion. Their diagnosis is much difficult as it could only get predicted when symptoms are shown. Anthrax is much widely used bioweapon during WWI. Due to use of weapons during wars it is also known as 'germ warfare'.

Pollution caused by nuclear bombs thrown out in Hiroshima and Nagasaki effects the environment and public health of people still today. War pollution caused due to these kind of activities effects the today's environment too.

To reduce these effects some preventive measures should be taken. To reduce the effects of bioweapons on public health proper vaccination is required. Some licensed vaccines are available in market for few bio-threats such as anthrax, small pox. Recently the U.S Strategic National Stockpile (SNS) provide enough vaccines to the population effected during bioweapon attacks. Researchers do their best to develop vaccines for other deadly bio-threats such as Ebola etc. (Biological Weapons, Bioterrorsim and Vaccines, 2018)

Bio-war is the intentional use of toxic biological agents such as: bacteria, fungi, molasses, and viruses etc to kill people. Biovar is not a today's world game instead it was being played since old times.

Following historical evidence shows some previously fought bio wars

Volume 8 Issue 10, October 2019

www.ijsr.net

Licensed Under Creative Commons Attribution CC BY 


\section{International Journal of Science and Research (IJSR) \\ ISSN: 2319-7064}

ResearchGate Impact Factor (2018): 0.28 | SJIF (2018): 7.426

Historical evidence of bio-war:

There is such a long history of bio-war. Its deployment can be a lo-fi case for example; it doesn't require any electrical material, nuclear weapons or rocket contents. Some examples as given in (Biological Weapons, Bioterrorsim and Vaccines, 2018) which shows the usage of bioweapons in our previous times are:

Usage of catapults to hurl the bodies of plague patients by Mongol attackers in 1346. (Siege of Caffa).

In 1763 (French Indian War) the British army gave infected blankets from the smallpox hospital to the Indians to weaken their stronghold.

Usage of 'rye ergot fungus' by Assyrians to infect their enemies well as this fungus contain the properties of LSDLysergic Acid Diethylamide.

In 1930-1940's plague was used as bioweapon during Sino-Japanese war by Japanese.

Accidental release of plague by Soviet Union in 1979.

The Rajneesh cult members infected salad bars in Oregon with Salmonella typhimurium in 1984.

In 2001 Anthrax infected letters were sent to the U.S. Mail office.

During World War II Japanese use plenty of BWs as they throw ceramic bombs filled with fleas carrying bubonic plague on Ningbo China.

According to (Newman, 2018)

"The Japanese army poisoned more than 1000 water wells in Chinese villages to study cholera and typhus outbreaks. Some of the epidemics they caused persisted for years and continued to kill more than 30000 people in 1947 long after the Japanese had surrendered."

The harmful biological agents used to kill people during wars are termed as Bioweapons. Different types of microorganisms (Bacteria, Viruses, Fungi) are used as Bioweapons. They are released in the form of aerosol sprays or directly into food and water sources. Majorly bioweapons are classified into three categories as:

Category A: These have high mortality rate, and these are easy to disseminate.

The bioweapons falls under this category are: Bacillus anthracis, Yersinia pestis, Francisellatularensis, Variola major, Filovirus and Arenavirus family.

Category B: They have moderate morbidity rate and are moderately easy to disseminate. The bioweapons in this category are: Brucella species, Salmonella species, Vibrio cholerae and Alphavirus family.

Category C: The Category $\mathrm{C}$ bioweapons are easy to produce and release. They have very high morbidity and mortality rate. The bioweapons under this category are: Mycobacteriumtuberculosis, Nipa virus and Hantavirus.

\begin{tabular}{|c|c|c|}
\hline Bacteria & Viruses & Toxins \\
\hline Bacillusanthracis & Variola virus & Cholera toxin \\
\hline$\frac{\text { Clostridium }}{\text { Perfringens }}$ & Rift valley & Botulinum toxin \\
\hline$\underline{\text { Clostridiumtetani }}$ & $\begin{array}{c}\text { Murray valley } \\
\text { encephalitis virus }\end{array}$ & Tetanus toxin \\
\hline Clostridiumbotulinum & $\begin{array}{c}\text { Omsk } \\
\text { haemorrhagic } \\
\text { fever virus }\end{array}$ & $\frac{\text { C.perfringens }}{\text { toxin }}$ \\
\hline Brucellaabortus & Looping ill virus & Trichothecenes \\
\hline Brucellamelitensis & Oropouche virus & Volkensin \\
\hline$\underline{\text { Yersiniapestis }}$ & $\begin{array}{l}\text { Dengue fever } \\
\text { virus }\end{array}$ & Shiga toxin \\
\hline
\end{tabular}

Some bacteria, viruses, toxins which can be/or being used as bioweapons are given in the table below: Source: (Alok Kumar, 2011)

Biodefense is an important factor which comes to play so as to safeguard the people from the harmful effects of the bioweapons. Some of the major challenges that come in the way are:

- Recognition of an attack and managing the disease.

- To analyse the specimen.

- In-situ specimen collection.

\section{Disaster Management:}

Handling of the disaster: Unless announced by the terrorists it is a big problem to detect the bioweapon because many of the times there will be hoaxes of such disasters. So, it is important that proper lab facilities are there to detect the samples and to prevent the disease from the samples by covering them. Usually triple layering is advised so that there will be no leakage of the sample. There should be prohibition on the visitors in the hospitals so that no more disease could spread. In case of high contamination, decontamination of the patients and the surroundings is advised. People should be made aware of the disease, it's mode of spreading, precautions and when and how to seek medical help. Proper routine check-ups of the people should be done. In case of spreading of the disease people within the reach of infection/infected area should be evacuated to safety as soon as possible.

The Biosafety/biodefense measures safeguarding the people are for combatants (army troops) and noncombatants (civilians).

Biosafety measures for army troops: The combatants should be provided with high class biosafety suits. They should be given Gas-masks like M61, 40mm NATO gas mask. Biosafety staff should be provided to the combatants which will take care of the infected personnel.

Biodefense for civilians: The civilians should be immunized at times to restrict the spread of certain infections. Blood tests of the civilians should be done at regular intervals. Civilians should be educated or made aware about the ongoing epidemic. In case of breakout of

\section{Volume 8 Issue 10, October 2019 www.ijsr.net}




\section{International Journal of Science and Research (IJSR) \\ ISSN: 2319-7064}

ResearchGate Impact Factor (2018): 0.28 | SJIF (2018): 7.426

certain infection the infected person should be quarantined.

Also, there are majorly two treaties which are signed by different countries which bans the production, usage and storage of these bioweapons.

The Geneva Protocol: The Geneva Protocol is a treaty that bans the use of chemical and biological weapons in any international armed conflict. The treaty was signed on 17 June, 1925 and implemented on 8 February, 1928.

\section{(wiki/geneva_protocol, n.d.)}

Biological weapons Convention: After the violation of The Geneva Protocol by many countries, the international community formulated a new instrument that would supplement the 1925 Geneva Protocol. The Geneva Protocol only bans the use but not possession of the chemical and biological weapons so a new treaty named "Biological weapons convention" was signed on 10April,1972 and entered into force on 26March,1975 that bans the usage, production and storage of any sort of chemical and biological weapons. There were total of 109 signatories and 182 parties. (wiki/Biological_Weapons_Convention, n.d.)

\section{Discussion}

\section{Modern aspects and Vaccination:}

Modern day bioweapons or bio-threats are used or caused via aerosol sprays, explosive devices, by infecting natural bodies or by using injections. Bioweapons being used presently have more potential to cause great harm than other hi-tech weapons, of course they are of low cost too.

The usage of these weapons by anti-national agencies are increasing because they took long to get detected (as symptoms are shown later). Handling of bioweapons is difficult as it can also infect the people using it.

Potential nosocomial transmission of bioweapons occurs through body fluids such as blood mainly. The necessary notifications and reporting of spreading of diseases in humans, flora and fauna helps as a source and dismissing the threats of bio-war agents and bio-terrorism. These practices helps in developing a reservoir of preparedness capacity.

Much of the scientific societies and worldwide initiators representing the worldwide threats of infectious diseases have been documented. African biotech community is fully aware of the fact for safety requirement and risk associated with development of capability of bioweapons by applying genetic engineering techniques to microbes. Damage of environment usually leads to wide spread of infectious disease. In South Africa, AIDS becomes an attention seeking disease because of its spreading.

Weapons whether the bioweapon, nuclear weapon or chemical cause mass destruction which leads to national insecurity. Bioweapons much commonly used because of its low price and of its ability to effect much wide population. Mainly civilians and military get affected more easily in wars by these weapons so it is very necessary to develop some vaccines or bio-detecting agents to overcome this tragedy.

Bio-robots can be developed as a bio-detecting agents. These bio-robots are mainly mechanized insects with computerized artificial systems; also known as microgadgets as microbes are used. They can carry out DNA processing, screening of blood samples, scanning of the identification of infectious genes or monitoring of gene cell activity etc. that are the activities mainly carried out by laboratory technicians.

Biosensors can also be used as bio-detection agents. Biosensors based on tissues produces alert signals of public health risks during bio-war and bio-threats. For instance; Halobacteriumsalinarum act as biosensor for optical computing artificial vision and data storage.

A major challenge for biotechnological industries is the production of effective bio-defence programs based on the basic research in biotech era, genetically engineering and information technology (IT). Biosensor technique is the major device which leads to the production of bio-chips for detecting

Pesticides, allergy causing agents and microbes.

Gaseous pollutants such as NH3, CH4 etc.

Heavy metals, phosphates, nitrates etc. in potable water.

Biological and chemical pollutants in food and beverage industries etc.

Victims of the bioweapons and rest of the population also requires the proper vaccination against bioweapons which is necessary. Rapid implementation of vaccines is much vital because in case of some diseases vaccinating after the exposure of disease have no effect.

Biosecurity experts suggest that passive immunization can be done with the help of agents and by this practice it can act as passive response to bioweapons during attacks. These immunization can gave immediate response or protection against the infection caused by bioweapons. Mainly passive immunization is provided for diseases such as botulinum toxins, tularaemia, anthrax and plague. Till today passive immunization is done only in animals and further conduction of these kind of experiments is going on.

\section{Environmental consequences of the bio-war:}

War has highly impacted the human life in many ways. War and other military activities cause health problems by their effect on physical, biological, economical environments of the people. During war much of the infrastructure, fauna and flora, civilians, combatants (military) and other natural sources like water bodies gets affected. Destruction of infrastructure lead to the shortage of food which leads to deaths due to starvation, 


\section{International Journal of Science and Research (IJSR) \\ ISSN: 2319-7064}

ResearchGate Impact Factor (2018): 0.28 | SJIF (2018): 7.426

contamination of water sources which leads to the many waterborne diseases.

While damage to physical environment-land, water, soil and use of non-renewable resources are the results of the wars or their preparations.

Biological environment gets damaged as a result of nuclear weapon testing, use and their disposal which release harmful radiations. Chemical weapons releases toxic substances during their production, use and testing. All of this leads to the increase in the diseases and also the environment gets contaminated. For instance, the use of nuclear bombs over Hiroshima and Nagasaki during. Second World War led to the sudden death of the people. The destruction caused by these bombardments is very vast over; 200, 000 people got killed. These bombardments caused the widespread of the radioactive contamination of the environment of these two cities. The land, air, water bodies of these two cities got highly contaminated due to the release of highly toxic radiations. The results of this inhuman practice can still be seen today as many new-borns of these cities are having innate genetic disorders.

\section{Future: Safe or to be Worried?}

Though bioweapons are much old as mountains, but modern era technologies bring out new worries because of the development of new techniques in biotech engineering. There are much recent advances in gene editing.

A gene editing technology also known as CRISPR has set off alarm bells in biodefense community; the techniques allow to edit the genomes thereby modifying the DNA sequences to alter the gene functioning. This technology also becomes cheap day by day therefore becomes more accessible for bio-terrorism. As in wrong hands it has potential for evil. A report titled "Worldwide Threat Assessment" by the U.S. Intelligence Community; has gene editing features in a list of weapons of mass destruction.

"Given the broad distribution low cost and accelerated pace of development of this dual-use technology; "he explains "its deliberate or unintentional misuse might lead to far-reaching economic and national security implications".

"By the advancement in genome editing in 2015 he continued "have compelled groups of high-profile U.S. and European biologists to question unregulated editing of the human germline which might create inheritable genetic changes."

Some federal bioscience research funds should be assigned to promote the development of next generation systems for environmental detection, medicated prophylactics and therapeutics. Successful implementation of a national biosecurity strategy will require integration of a variety of independent efforts across the federal bioscience research and public health communities. (Newman, 2018)

\section{Conclusion}

Attack of bioweapons by anti-national party is a remote possibility that nevertheless demands public health emergency response planning. Various multi-agency simulations exploited weakness in their systems designed to give valuable response during bio-warfare.

Some attempts made to regulate the organization of wars and in development of bioweapons or weapons containing poisonous substances are incorporated in conventions drawn up in respect to the laws and customs on land area.(Biological Weapons, Bioterrorsim and Vaccines, $\underline{\text { 2018) }}$

All these activities help us to know the need and requirement of strong bio-defence techniques as bioweapons can overwhelm the medical implementations and can cause widespread illness and leads to death and social and economic interference.

For neutralizing the effects of bio-agents and made them ineffective for their use as bioweapons; industries now focusing upon the production of wide range of vaccination techniques with the help of bio-based defence science and exploited technologies. As biosensors are the criteria on which researchers are focusing to make them capable as bio-weapon detecting agents. The aim of such techniques is for immediate detection and diminishing of bioweapons as reflected in "Sherlock Holmes 'dog doesn't bark" i.e. the silence of the sensor dictates the presence of a biological agent.

Facilities of the genome screening of the disease caused and the production of its particular drug by advance technology methods advances the era of bioinformatics. The computerized study of information on genomic DNA tandem with the digital processing and graphic computation techniques offers a stand for the development of devices for controlling environmental depletion and development of biodefense programs.

Modification of genetic engineering techniques and evolution in infected microbes became a big problem that can't be ignored. But due to the increasing concerns of the people towards the safety measures of protection from the disease caused due to these genetically modified infectious microbes helps to overwhelm the unsupported fears and misconceptions and to secure the confidence to state of preparedness.

Regardless of long bequest of depletion of environment due to these warfare most of the protocols and treaties are insufficient in reducing these destruction. But the main concentration of Law of War is on daily and basic human requirements. Increasing the awareness towards that the national security and ecological conservation they both are not separated from the security of environment increases more protection measures into consideration. 


\section{International Journal of Science and Research (IJSR) \\ ISSN: 2319-7064}

ResearchGate Impact Factor (2018): 0.28 | SJIF (2018): 7.426

Cabalism to the biological and Toxic Convention fortified by conviction increasing steps (UN 1997) is undeniably crucial and needy measure towards the reduction and obliteration of bio threats due to bio-wars and thus leads to bio-terrorism.

Though government has made such of policies and rules towards the awareness of environmental issues but we are so far and it takes so long to recognize such detrimental effects of war on natural environment and on public health.

In spite of such rules treaties and policies these issues are not more than newspapers headlines or topic of discussion on paper written work or the contents to be discussed on events to seek the attention of people only for some personal benefits. But this is a major issue because it affects environment, our natural resources and public health.

\section{References}

[1] Biological warfare, bioterrorism, biodefence and the biological and toxin weapons convention (Edgar J. DaSilva \{Director Division of Life sciences, UNESCO France $\}$ )

[2] War-water, effects, environmental, United states, history, impact, soil, industrial, wells, toxic, world, humans, sources, use, life, health, oil, history \{http://www.pollutionissues.com/Ve-Z/War.html \}

[3] Biological Weapons, Bioterrorism and Vaccines \{https://www.historyofvaccines.org/index.php/conten t/articles/biological-weapons-bioterrorism-andvaccines\}

[4] War and Environment: An Overview (Anusha Dubey and Priyanka Dwadsah Shreni \{Hidayatrullah National Law University, Raipur (INDIA)

[5] Review Paper: Biological Warfare, Bioterrorism and Biodefense (Alok Kumar, Archana Verma, Mukesh Yadav, Imran Sabri, Ashish Asthana)

[6] Biological weapons and bioterrorism: Past, present and future (By Tim Newman: published Wednesday $28 \quad$ February 2018) $\{$ https://www.medicalnewstoday.com/articles/321030 .php

[7] Prevention of War and its Environmental Consequences (Victor W. Seidel, Barry S. Levy and Jonathan E. Slutzman) 